\title{
A COSMOPOLITAN MANUAL IN DECOLONIZING AFRICA - FRY\&DREW'S TROPICAL ARCHITECTURE IN THE DRY AND HUMID ZONES
}

\section{A B S T R A C T}

Edwin Maxwell Fry and Jane Drew are best known for their role in the construction of Chandigarh alongside Le Corbusier, however their Indian experience was proceeded by a long career in West Africa that began during WWII and lasted until the end of the 50's. Fry\&Drew were active in Ghana and Nigeria constructing an impressive amount of buildings: schools, universities, houses, villages, office buildings and museums. Their on-site experience was conceptualized in the book Tropical Architecture in the Dry and Humid Zones published in its final version in 1964. This paper aims to analyze the manual as the attempt to establish a cosmopolitan and modern design system specific for the tropical areas. An experimental and scientific approach that saw in climatic data a tool in the creation of a new rootedness of modern architecture not based on cultural analysis or vernacular reinterpretation but on the complex analysis of local conditions in order to provide inhabitants with suitable design solutions. Tropical Architecture in the Dry and Humid Zones as a manifesto of a regionalist modernism, two apparently opposite terms that find a reconciliation in a design system that seeks to build a new cosmopolitan modernity. 


\section{FROM PIONEERS TO TROPICAL ARCHITECTS}

The manual Tropical Architecture in the Dry and Humid Zones, published in its final form in $19644^{1}$, is the highest point of Edwin Maxwell Fry's and Jane Drew's careers. Two careers that witnessed a close relationship with the great masters of modernism, Gropius and Le Corbusier above all, found in the manual the end of a long cultural journey and the attempt to establish an innovative design system specific for the tropical areas. The effort of these pioneers envisioned a scientific and technocratic attitude attempting a reconciliation between modernity and underdevelopment ${ }^{2}$. A regionalist design system, deeply rooted in climatic and geographical features, but at the same time an anti-localist one, far from any kind of vernacular tradition and any claim of cultural analysis.

The African design experience, fully concluded at the publication of the volume ${ }^{3}$, is highly visible in the manual. The design freedom and experimental attitude allow the African buildings to be the most innovative of Fry\&Drew's career and the best application of quantitative factors to architecture. Fry in his diary stated: it is hard to imagine a more romantic architectural program that this that took us in long journeys to sites, some of them deep in the forest, other atop ridges rising atop the tree level or looking at the ocean. Each school or college was different and each was a new venture an experiment pushing our knowledge and skill a stage further in our collaboration with nature. I was never more happy in my entire life $e^{4}$. The manual is the result of a long and sedimented work experience; single buildings can be seen as useful experiments conducted in order to understand and solve specific design issues. The examples in the manual come from the numerous modernist experiences in tropical areas: the African works of Fry\&Drew are predominant alongside those of a group of British architects who emigrated in the same period in Ghana and Nigeria: Architects' Co-Partnership, James Cubbitt\&Partners, Godwin\&Hopwood and Nickson\&Borys.

The text is a conceptualization of the designed buildings in order to understand influences and relations, the on-site constructive experience was translated into a set of rules and data in order to establish quantitative parameters and design tools useful for future colleagues. The introduction of the book clearly states this intent in a passage which can be considered as the true dedication of the manual ${ }^{5}$ : We write (...) for the growing number of those who inhabit this regions (...). On these architects and planners falls the major burden of creating an environment in which the tropical people may flourish. (..) So will the future architects who build for their own tropical people bring to their tasks, emotions, sympathies and knowledge denied to us who come from outside ${ }^{6}$. It is a dedication that acknowledges the colonial character of Fry\&Drew's presence in Africa and their cultural debt to British colonial culture. Fry\&Drew emphasize 
the value of cultural belonging of a designer to the society for which he designs, the ability to understand subconscious desires and future changes. They felt like pioneers and initiators of a journey that necessarily was to be made with different tools and methods; but intended to showcase their work as an orderly system of useful experiences. The ultimate goal of the manual was to identify a design system capable of providing a scientific rooting to architecture. A system that reduces the context in a series of data, removing any cultural localism. A design attitude respectful towards resources and in search for a new modernity that, from tropical areas, could become a universal example.

According to Fry\&Drew the process of ideation of an architect is totally internal to his mind, it is a personal artistic process that responds directly and solely to knowledge, feelings and experiences of its creator. The eruption of modern science in society has brought tremendous opportunities as well as problems: the machines have enabled a dramatic increase in production speed while destroying artisanal knowledge, medical science eradicated deadly diseases, industry polluted air and land. The emerging problems of the industrial city and of the developing tropics are not due to the failure of science but to the failure of the ability to assimilate and applying science for the common good: the ultimate goal of Tropical Architecture was interpreting applied science in humanistic terms (...) how seriously and with what addiction to truth must we perform each of us our commissions as creators of this future matrix of tropical existence ${ }^{7}$. In the book Fine Buildings, written in 1942 by Fry on the ship that took him to Africa with the British Army, he states: the reason why an architect should attempt to find an answer to problems that appear to lie beyond the problems of architecture itself, are understandable. Architecture has been divorced from its major tasks for the last century. Of all arts the most social it has catered only a minority of society ${ }^{8}$. The book is a critique of the consequences on the urban form, on society and on nature of the industrialization process because

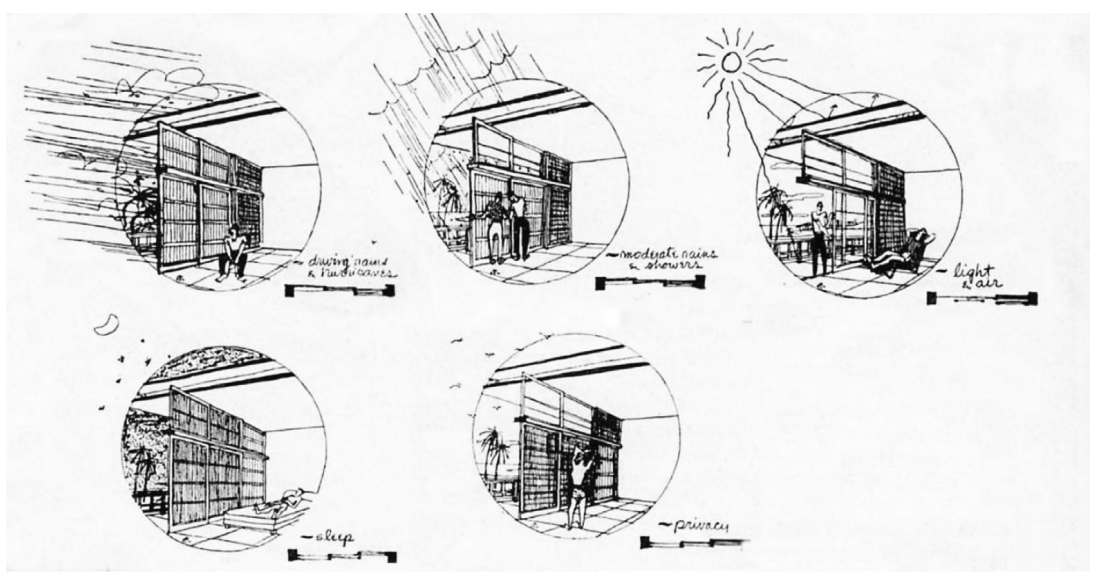


our civilization has complicated itself in way that hurt us, and because we are more active then we are thoughtful or observant we go on with the complication thought it still hurts 9 .

Progressive ideas presented in Fine Buildings found in the Africa a new vigor and the urgent need to find new methods and approaches. An attitude that goes beyond the creativity of the single architect through a quantitative process able to clear any sentimental attitude towards design. Architecture as informed creativity, practical and devoted to society as a whole. Echoing Gropius' words design is neither an intellectual nor a material affair, but simply an integral part of the stuff of life, necessary for everyone in a civilized society ${ }^{10}$. For Fry, as for Gropius, it is impossible to transform design in a fully scientific act but it is important to awake the designer from his particular world and reinstate him in the real world by anchoring his inventions to scientific processes. It is important to run away from any statement of "art for art's sake" but also from the industrialist threatens of "business for business' sake" in order to reach beauty that in architecture is derived from the search for functional solutions. Thought art is the final product of architecture and the creation of beauty the very proper aim of all good architects, there is no other means of finding it then through the exact and intimate fulfilment of a series of useful purpose and function ${ }^{11}$. Fry states that only by achieving functional goals architects earn the right to be considered useful members of society, practical and able to exercise common sense. This condition is most important in the tropics because the magnitude of the errors that can be committed is much higher and the social context much more fragile. The quantitative architecture proposed by Fry\&Drew in Tropical Architecture can be considered as the systematic organization of a series of previous experiences in order to achieve practical results: the fact that the architect is doing something useful is his constant and most important justification ${ }^{12}$.

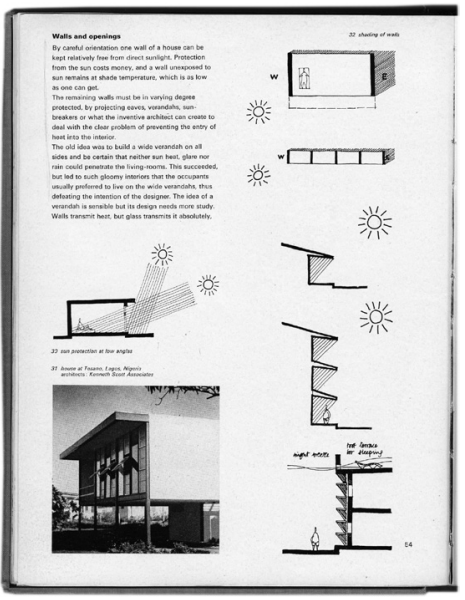

Figure 2. Edwin Maxwell Fry and Jane Drew, Tropical Architecture in the humid zones (London: Batsford, 1956), 54

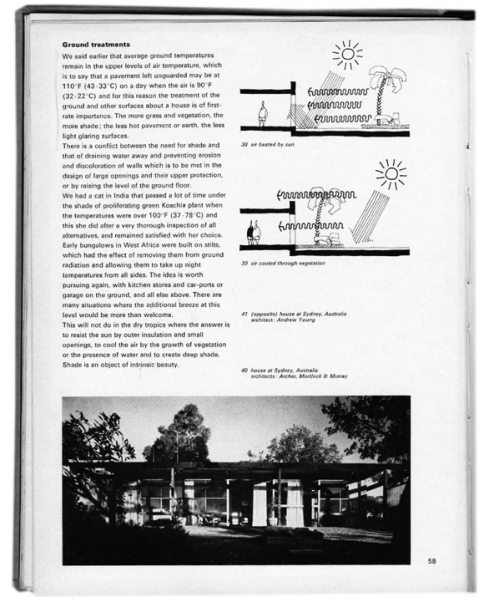

Figure 3. Edwin Maxwell Fry and Jane Drew, Tropical Architecture in the humid zones (London: Batsford, 1956), 58. 


\section{THE PARAMETERS: CLIMATE, POPULATION AND MATERIALS}

The manual presents three parameters that influence architecture in the tropics and that according to Fry\&Drew must be analyzed more carefully than in the temperate areas: materials and construction systems, population and its needs and climate. The selection of materials should be accomplished according to the skills and traditions, or to the possibility of breaking them to establish new skills and new traditions, it must be a wise and long term choice considering not only the cost and immediate qualities but also the development in time and the possibility of exemplarity and dissemination. Structural choices are particularly important for Fry\&Drew and in most projects are entrusted to Ove Arup ${ }^{13}$. We are testing, as closely as we know how the capacity of our civilization to perform one of its most important acts, we are giving it another and another chance of proving that it can rise superior to its circumstances and force the intractable materials and powers of nature to perform a service to man $^{14}$. The selection of materials and techniques should be considered as part of a long-term process that abandons the narrow contingencies to open up to further considerations on production possibilities, resources and craftsmanship always keeping in mind the process of incessant development of tropical areas. The ability to comply with and take advantage of circumstances is the key factor.

However research on materials in the African buildings is minimal: the use of local stone is limited to the base of the buildings such as in the Ibadan Library, or where the transportation of materials becomes prohibitive as in Amedzofe School ${ }^{15}$ in Togoland. The few construction site photographs available testify how the structures were made using modern cast concrete methods exploiting the huge workforce to perform processes there were normally mechanical ${ }^{16}$. The buildings of Tropical Architecture fully explored the constructive possibilities of concrete using it both structurally as well as for the finishing and were

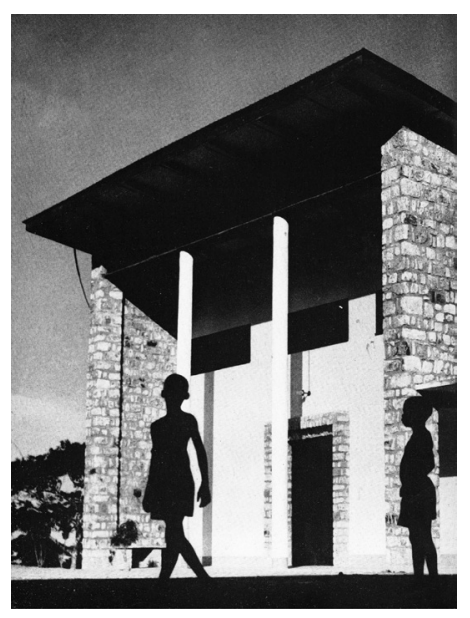

Figure 4. Amedzofe School Edwin Maxwell Fry and Jane Drew, Tropical Architecture in the humid zones (London: Batsford, 1956), 154. 
constructed by European companies ${ }^{17}$ employing local labor. The finishes and the elements subject to climatic stress such as the sun breakers were constructed with imported materials like asbestos and steel panels or with full production lines transferred to Africa like the breathing wall with African motifs in precast concrete $^{18}$. One of the few attempts to update the traditional materials was the swishcrete, a mixture of raw cement and earth, baked in the sun in wooden molds used by Alfred Alcock ${ }^{19}$ in the construction of the Asawasi village near Kumasi.

As for population and its needs Fry\&Drew stated as a preliminary consideration the impossibility of the inhabitants to fully understand their own needs. Especially in evolving urban and social contexts it is impossible to follow directly the demands of the population. Following a question already posed by Gropius the architect's task was to serve or to lead? For Gropius as Fry\&Drew the answer is, ambiguously, that the architect's task was to serve and lead. But if the human factor is becoming more and more dominant in our work, architecture will reveal the emotional qualities of the designer in the very bones of the buildings, not in the trimmings only; it will be the result of both good service and good leadership ${ }^{20}$. For tropical areas the theme of population and its needs is much more complicate then in the Western world, clashing with the presence of ancient traditions and constant changes. Local traditions are changing between different age and wealth groups, the younger and poorer welcoming and the older and richer resisting change ${ }^{21}$. In the manual an example is the construction of Tema Manhean ${ }^{22}$ where the initial design proposed by Fry\&Drew provided homes with a unique interior space inspired by the traditional Ashanti hut. The African members of the construction commission required a more European distribution, configuring homes with services and functions closer to western culture.

Change goes beyond any sentimentalism, as the characters of George Orwell's Burmese Days the roles are reversed the conversation between the British officer Flory and the local doctor Veraswani is very significant; Flory claims that British rule did not bring progress if not in the form of more banks and more prisons and destroyed all forms of local culture while Veraswani answers that modernity is represented by hospitals and schools concluding: your civilization at its very worst is an advance for us, I see the British as torchbearers upon the path of progress ${ }^{23}$. The Western, while recognizing the need for development, retains a romantic and idealistic eye identifying colonialism with a a prison. The colonized instead craves modernity, even in its most extreme and globalizing forms, representing forced development with schools and hospitals, universal symbols of rationality and righteousness ${ }^{24}$. Change is inevitable for Fry\&Drew, the architects are responsible of using it as a design material designing buildings 
and towns conceived with sufficient generosity and imagination to allow of the fullest exercise of expanding consciousness, and to meet the complicate mechanism of modern life without sacrificing human freedom and dignity in the process ${ }^{25}$.

Climate is the most important factor and the true discriminator of architectural form, the entire chapter after the introduction is dedicated to this subject. Tropical climate is described in its overwhelming force, burning sun with torrential rains brings to life an unending cycle of massive vegetation, dwarfing man by the vigor of its growth, and accompanied by an insect and parasitic life more deadly than the large animals of the jungle $e^{26}$. The considerations on climate adaptation show a continuity with the colonial world, the nineteenth-century behavioral codes have been cleaned of all racial connotation but remain as valuable tools working upward from the delightful minimum that is all that tropical life requires ${ }^{27}$. The undramatic vision of tropical life is tested by the increasingly close relationship of colonial areas with the modern world that has set for itself the goal to subjugate nature to its own purposes on a planetary scale. The buildings are a tool for the control of nature, only possible through the development of systems of scientific analysis of climate. It is possible to change the climatic perception by applying knowledge to produce an architecture suited to the needs of the occupants and to the available resources. The analysis of different climatic features allow to divide the tropics into two main areas: dry and humid tropics, and in five sub-categories defined by a series of scientific parameters. The process of scientific definition of climate is continuously mixed with design considerations and cultural influences. AS an example the information on solar radiation and temperature, according to climatic areas, do not remain cold data but can instantly be transformed into shadow patterns and minimize solar penetration through instruments such as the shadow-angle protractor ${ }^{28}$.

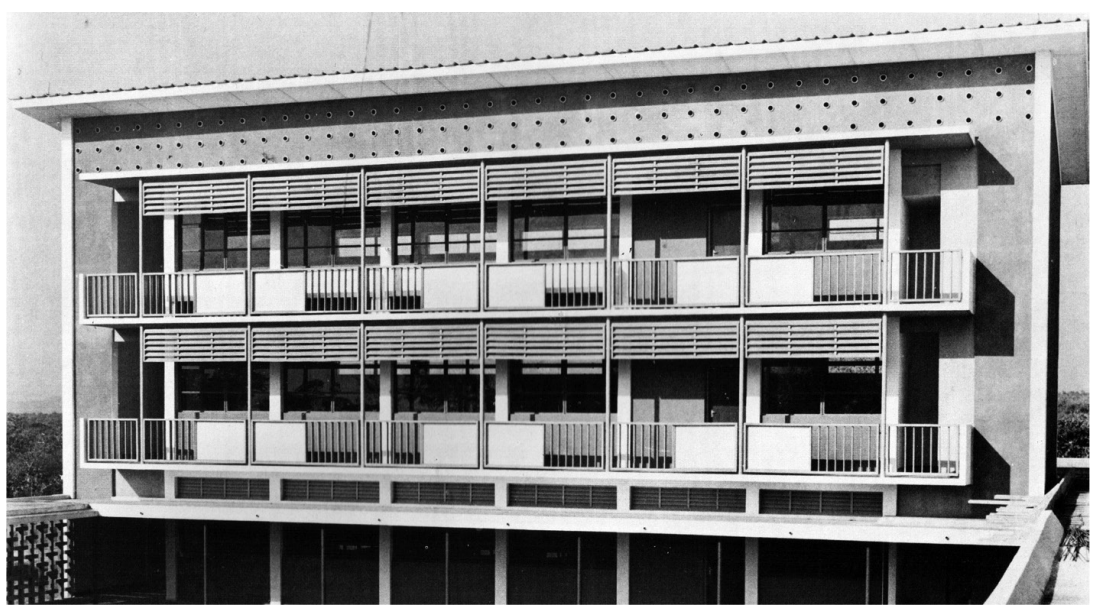

Figure 5. Fry\&Drew, Mawuli School, Ho, Ghana, 1953 from Fry, Drew, Knight, Creamer, Booklet, 1977. 
The proposed tools lead to a generalization of the dry tropics as areas where heavy shade internally, exclusion of intense glare and dust penetration are primary factors in the design and orientation of buildings. Humid tropics instead demand shading externally by means of large overhangs and other devices which also give protection from driving rain ${ }^{29}$. An additional step links cultural considerations to climate, living habits shaped by centuries of confrontation with environmental harshness. Dry tropics are places where the daytime life usually takes place at home and social gathering are confined to afternoon hours, activities take place inside houses while sleep on the roofs. In the humid tropics social life takes place outside, while sleep inside, the day is regulated by two periods of light and darkness equal and seasonally unchanged. Climate becomes an all-encompassing factor that can incorporate any cultural difference, climatic analysis goes beyond narrow disciplinary boundaries and becomes a multidisciplinary design act. From climatic analysis to climatic design, a complex tool in which data becomes a design source. Climate is a new regionalist factor that can erase any imitative sentimentalism and every fashion, leading to the understanding of the fundamental differences imposed on the design process by the minimum climatic differences. Building in the enormous tropical belt becomes solely a climatic problem ignoring any cultural and political factor. Fry\&Drew worked on the construction of an imaginary world where the political processes of liberation and decolonization had already occurred, without violence and social unrest, and where the only goal was modernization, in search for new cosmopolitan roots ${ }^{30}$.

\section{THE HOUSE, DEMONSTRATION OF CLIMATIC DESIGN}

Clarified the terms of analysis the manual proceeds with a functional distinction of buildings, specifying problems and tools in order to identify design solutions. The functional distinction is borrowed from previous experiences of the colonial period, in particular engineer's building types ${ }^{31}$. The structural choice of the manual is in part unjustified, diagrams and data can be applied to different functions, and the distinction is more an organizational pretext rather that a real need. The overall work allows a careful reader to be equipped with a set of tools with the ultimate goal, full of progressive optimism, to transform architecture into a development tool. The first function analyzed is the house, used as an example of climatic design. Although the first images of the chapter show examples of traditional dwellings, any traditional type is abandoned and substituted with issues such as orientation, roof systems, walls and openings, soil treatment, ventilation, protection from insects and termites, lighting and furniture. The house as an archetypal element, not of the primitive shelter common to all cultures, but of design based on climatic features. Fry\&Drew address the problem as a mathematical theorem: we propose to demonstrate 
the family house because it is generally understandable, its functions are aspects of family life and have a large degree of universality; once understand the problems of the house and much else becomes clear ${ }^{32}$. The new rootedness of tropical architecture can be found by facing technical issues, the modern tropical identity arises from the confrontation with climate and this regional language unites areas with similar climates rather than geography or culture.

In reality houses are not among the main functions explored by Fry\&Drew in West Africa. The distinction between Europeans and Africans remained clear even in the transition towards national states, and the few houses constructed were villas built for Europeans or for large industrial companies. Two works by Architects' Co-Partnership ${ }^{33}$ are useful in order to demonstrate the approach: House at Kano ${ }^{34}$ built in1959 and Shell/BP House ${ }^{35}$ built in Enugu in 1957. Kano is located in the dry tropics while Enugu in the humid ones; this distinction allows to read the advices in the manual identifying points of contact and differences. In both climates the best solution for the residence is a two-story building with the living area located on the ground floor, with a massive structure of stone or concrete protecting from the daytime heat, and the sleeping area on the upper floor. The main differences emerge in the upper floor: in the humid area the most urgent need is to maximize ventilation, in the dry one protection from dust storms and heat release accumulated during the day.

The identification of clear goals and the selection of climatic features to be faced becomes the first design act and leads the upper floor to opposite solutions in the two houses. The Shell/BP House has a light structure, in which the opaque outside walls disappear and are entirely substituted by louvre windows that maximize ventilation. Instead of Mies Van der Rohe's house of glass it would be a house of air (...) ideally the hot-wet tropical house is a thing of point supports, a light framework allowing the maximum of opening ${ }^{36}$. In House at Kano on the contrary, openings are minimized and air exchange is entrusted to an inner

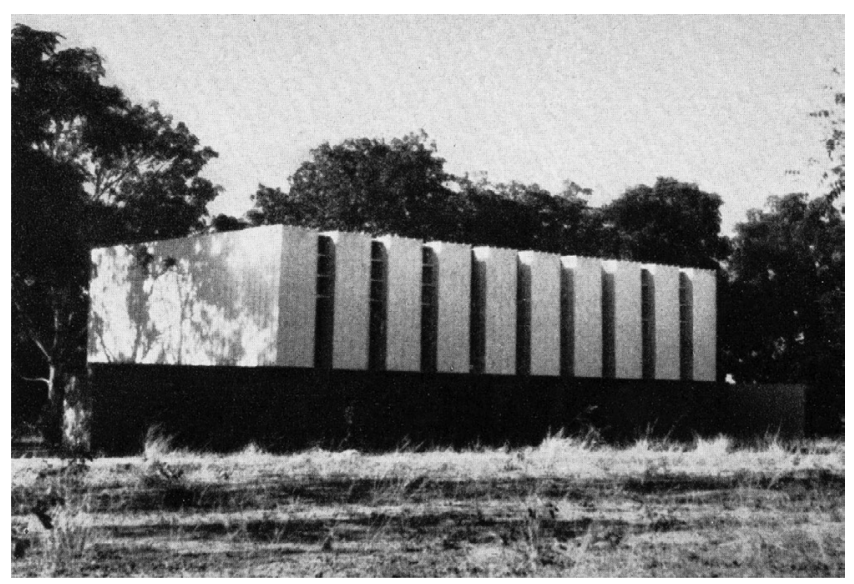

Figure 6. Architects' Co-Partnership, House at Kano, Kano, Nigeria, 1959 from Edwin Maxwell Fry and Jane Drew, Tropical Architecture in the humid zones (London: Batsford, 1956), 71 
patio. The patio, a typical feature of the area, is re-proposed strictly for climatic reasons, attention to conditions of climate leads most directly to a strongly marked character of building appropriate to the region in which occurs and satisfactory to its inhabitants ${ }^{37}$. Climatic considerations lead to the construction of two buildings that start from similar concepts but reach completely different conformations. In Kano the heavy stone structure completely defines the building and outdoor spaces, while the upper floor is brilliantly solved by the use of lightweight aluminum elements that can quickly disperse the heat accumulated during the day. In Enugu the structural pattern is mixed, concrete walls delimitate interior spaces on the ground floor and are wrapped in a structure of wooden pillars with a veranda running around the entire building. The veranda, which had been the dominant device of colonial architecture, is criticized and modified by the designers of the Tropical Architecture. While acknowledging the climate benefits of an external structure it is underlined how the old idea was to build a wide verandah on all sides, this led to such gloomy interiors that the occupants usually preferred to live in the veranda $a^{38}$, abandoning the rest of the building. The solution proposed in Enugu is a minimization of the veranda transforming it in a simple space for external circulation while in other designs this device is replaced with elements such as sun screens, canopies, breathing walls or projections of the floors: all possible solutions in order to defend the internal space from direct radiation without sacrificing natural light.

As an evidence of how Fry\&Drew are more interested in tools rather then in specific solutions, other examples of tropical houses provided in the manual range from the Indian project of Le Corbusier and Balkrishna Doshi ${ }^{39}$ to Paul Rudolph's Cocoon House ${ }^{40}$ and Pancho Guedes' Mozambicans buildings ${ }^{41}$. An interesting example comes from another British firm that found fortune in West Africa in the 50's: James Cubbitt \& Partners ${ }^{42}$ in 1953 built in Accra the Einhorn House $^{43}$, a simple building that keeps the manual setting of a two-floors residence with a lower living area and an upper sleeping area.

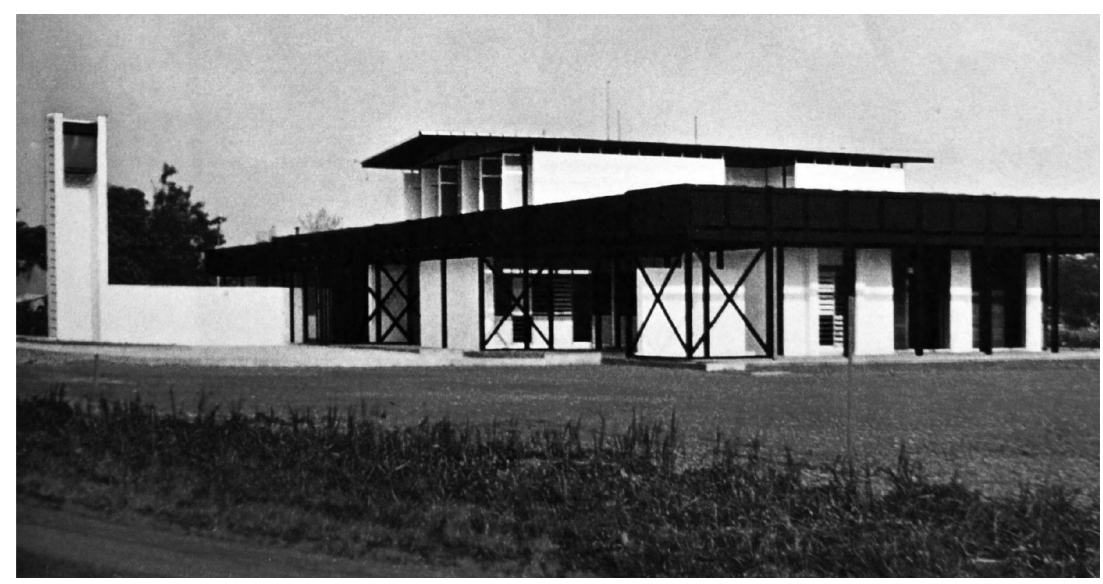




\section{PUBLIC BUILDINGS, NURTURE SOCIAL HUMUS}

Civic and community buildings are a fundamental part of life in the tropics. The communitarian nature of society makes the construction of public spaces more important then the quality of housing. The model of the traditional village in which public, commercial and manufacturing spaces tend to overlap and blend was re proposed since the 40 's, in the in-becoming metropolis generating the need to establish public spaces able to strengthen community bonds while allowing modern lifestyles. The emergence of modern production systems led to a modification of public spaces. On the one hand the mechanization of work was to enable, in a progressive vision, an increase in leisure time ${ }^{44}$, on the other large domestic migrations and new arrangements of unhealthy neighborhoods threatened to disconnect secular social ties. The marketplaces of Cairo or Kano, which had been for centuries fundamental meeting places, were considered by the colonizers more as a danger to public health than as an engine of a society in impetuous change. The new public buildings had to be modern spaces of progress able to renew without destroying a solid and ancient community tradition. It is significant the choice by Fry\&Drew to commission for their Civic center in Accra a mural by Kofi Antobam ${ }^{45}$ depicting a group of people in traditional $\mathrm{Ga}^{46}$ costumes with the inscription it is good to live together as friends and one people, an idealized image of pre-colonial culture and national unity that seeks to establish a continuity partially denied by the modern form and function of the building ${ }^{47}$.

Gropius emphasized the importance of public and community places in order to cultivate the social humus, the bonds of help and sharing between neighbors. The community is for Gropius a functional organization of society in which houses are cells and organs and the civic center is the heart, the coordinator of a potentially rich and diversified life from which the branches of all social arteries that determine the character and shape of a whole group are born ${ }^{48}$.
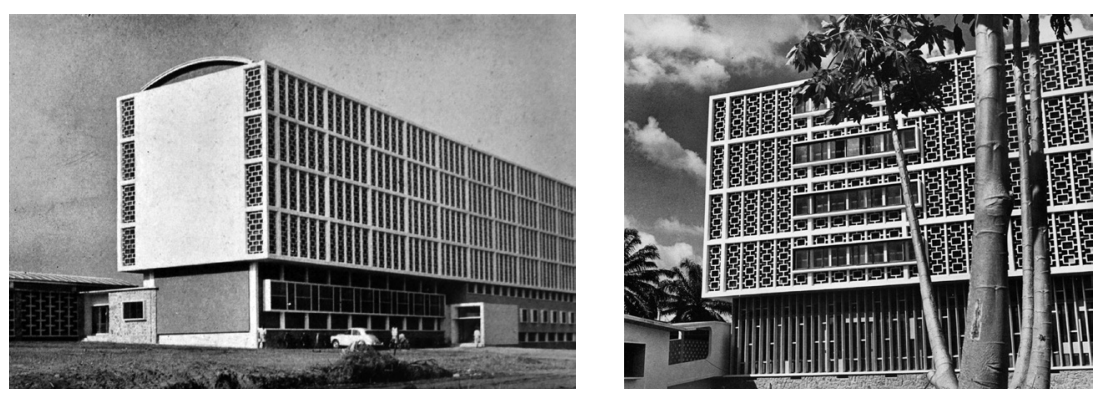

Figure 8-9. Fry\&Drew, Ibadan College, Ibadan, Nigeria, 1951 from Fry, Drew, Knight, Creamer, Booklet, 1977. 
The manual actually tackles the topic of civic spaces in a rather superficial way through a call for the creation of public spaces that take into account different environmental conditions and, consequently, lifestyles. Fry\&Drew show on one hand the appreciation of African traditions and on the other the will, considered almost necessary, to modify them: old Kano city was beautiful because it had come to terms with the circumstances and achieved harmony. Beautiful but insanitary. The new part of Kano is sanitary, but it's formless, ugly, it has not come to any solution. What is therefore to be the form of a new Kano concerns the structure of living and working under the burning sun. It calls for the structure of a solution, what the scientist would call a model hypothesis that can be seen and tested from all sides ${ }^{49}$. The manual does not further develops the theme of public space, but it is possible to analyze some buildings to understand whether these hypotheses can be confirmed or refuted. The most important public building constructed by Fry\&Drew is without a doubt the Kenneth Dike Library at the University of Ibadan, considered by Fry the masterpiece of his career. The construction of Ibadan College in Nigeria, whose institution is in part due to the political work of Julian Huxley ${ }^{50}$, was an opportunity for Fry\&Drew to test their working method in a large-scale project with a considerable number of buildings with different functions: teaching rooms, residential colleges, theaters. The allocation of the project to Fry\&Drew is partly due to the full availability to employ African designers in their London studio where they would be exposed to the full mental rigors of an architect's office at work ${ }^{51}$. Again fascination and paternalism mix and mingle.

The public space of the library is created with a very simple distribution pattern: on the ground floor the reading and consultation rooms, topped by four floors of book warehouse protected by overhanging verandas on the main facades. The building is dominated by the presence of a huge breathing wall, a combination of horizontal and vertical sun breakers adaptable to any orientation and able to allow the passage of indirect light and ventilation while blocking rain. The library is an experiment with the principles of natural ventilation with the ultimate goal of protecting the central core of the deposit. The climatic device assumes the size of the entire building structure, and is made up of several cooperating elements. The structure allows the realization of a overhanging veranda, the veranda protects the central element from the rain, an internal frame buffered with mosquito nets protects books from insects, the breathing wall protects the nets and at the same time allows maximum ventilation. The climatic device is not simply the breathing wall but the complete building structure that addresses all the different problems posed by the tropical climate and the functional program. The manual shows the method of calculation of the sun protection provided by a breathing wall with respect to latitude and 
orientation, considering the sum of trigonometric calculation for horizontal and vertical elements. The public space is shaped as a formidable architectural and climatic machine in a way that does not take into account any cultural or historical factors.

The hypothesis of Ibadan, the simple application of a Western model with sophisticated climate control systems, was picked up by other designers: the Ghana National Library ${ }^{52}$ constructed by the London based studio Nickson\&Borys ${ }^{53}$ in 1957 is an example. Although dimensionally and distributively different, the building reaches a solution very similar to that of Kenneth Dike Library. The lessons of Fry\&Drew, whose buildings were continuously published on the main British architectural magazines of the 50's, were beginning to bear fruit. The pioneering experience revealed errors and naïveté and allowed the generation of younger brothers, waiting for African designers, to further carry forward the search for quality solutions. In Accra, the structure is considerably simpler and the breathing wall is used as the only barrier between the book deposit and the outside. The treatment of the facade is the central theme, the breathing wall has a greater depth becoming a fully three-dimensional element and dictating, using a sequence of closed and open elements, the building's internal distribution. The entrance element with the cantilever roof and the spectacular curved staircase is entrusted with the task of breaking crigid geometric pattern of the facade. The breathing wall of Accra is an evolution of the one in Ibadan thanks to the increased depth of the facade. Fry himself realized the excessive two-dimensionality of the Nigerian solution stating: the grille work is really to light in section ${ }^{54}$.

The last public building built by Fry\&Drew in West Africa is symptomatic of the conclusion of a journey: it is the Ghana National Museum ${ }^{55}$, a gift left by the British for Ghana's independence in 1957. The building is an example

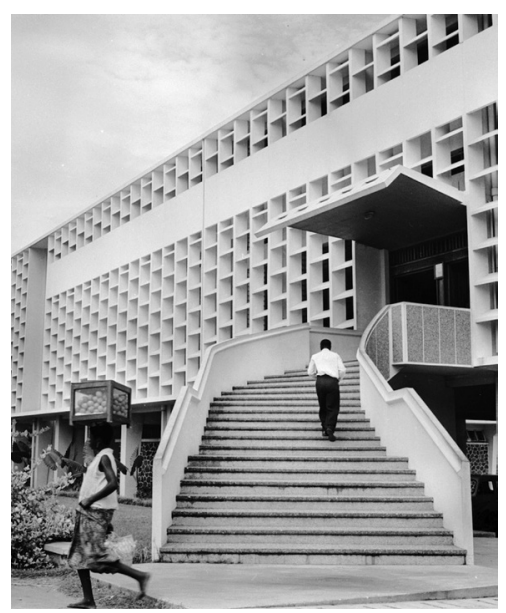

Figure 10. Nickson \& Borys, National Library, Accra, Ghana from Getty Imagines. 
of Tropical Architecture and at the same time a symbol of the new nation. Introducing a new architectural type, and a new institution in the country, it was intended as a tool to demonstrate the richness of the Ghanaian culture and at the same time the search for a Panafrican identity. The museum, likely designed by Lindsay Drake ${ }^{56}$, is dominated by an imposing central dome made of prefabricated concrete with a base intelligently designed with zigzagged walls ensuring maximum internal ventilation in the exhibition space. Natural lighting is ensured by a careful study of light reflection systems that avoid direct radiation but allow sunlight to bounce off the dome giving a diffused light effect in the entire exhibition space. The symbolic significance of the work brings to extremes a set of concepts that are the basis of all the buildings of Tropical Architecture. A fledgling nation, breaking the chains of colonialism, builds a museum as a founding act. The museum is in large part the product of colonial curators and display systems, but intends to build a national and Panafrican identity, encouraging the development of historical consciousness amongst the peoples of the Gold Coast, an essential and urgent function because of the recent growth of national consciousness ${ }^{57}$. The National Museum as a symbol of a transition that cancels the colonial period by putting in direct continuity pre-colonial cultures with in-becoming nations. The central dome as an iconic element of a new modern national pantheon, that can accommodate a selection of the best parts of tradition. The emergence of a nationalist sentiment, completely alien to African culture, is an attempt by Kwame $\mathrm{Nkrumah}^{58}$ to deny the inferioritlearly stating that an underdeveloped region can self-develop while preserving its identity. The operation links the aspirations of progressive colonizers with those of the local elite, presupposes a past, it is summarized however in the present by a tangible fact, namely, consent, the clearly expressed desire to continue a common life ${ }^{59}$. Common life ignores any linguistic, race, religion or geographical difference is an invention and as such needs new cultural and technological tools.

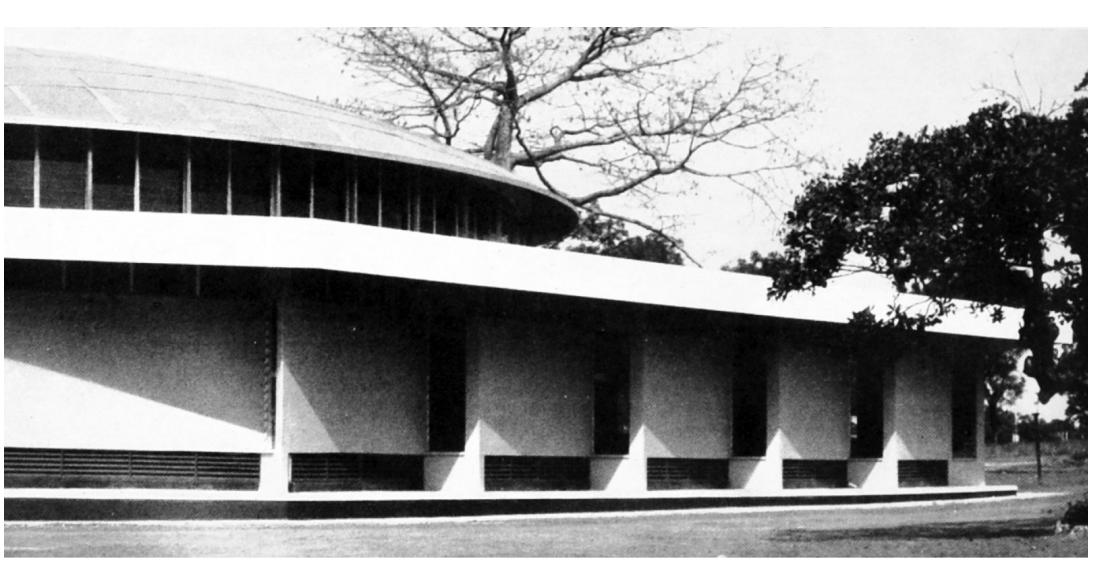


Tropical Architecture interpreted the feelings of African elites aspiring at a cross-cultural world in which the internationalist and progressive values of modernism are guides towards a common future, modern and cosmopolitan. The National Museum is an architecture that tries to combine modern and local identity by denying critical issues, differences and diversity; an act of voluntary forgetfulness (first of all of colonialism) that allows the emergence of a possible but still only imaginary Africa ${ }^{60}$.

\section{SCHOOL BUILDINGS, CITADELS OF RATIONALITY}

Schools are the functional typology mostly addressed by Fry\&Drew in their African experience and the tool selected by the progressives colonizers to influence the future development of Africa. Literacy is necessary to democracy, as higher education is to government, and where the pace of advance brings rapid development to both, education must extend over a wide front embracing every form lying between primary education and specialised research at pressures corresponding to the resources available ${ }^{61}$. The British during the decolonization process considered schools the main instrument of development in order to produce a well-educated class of young leaders. The methods used by the British in the construction of schools did not vary from the colonial period. School buildings were powerful symbols of citadels of rationality, strengthening local beliefs about the prestige and superiority of western culture $^{62}$. The schools built by Fry\&Drew in Ghana in the second half of the 50 's fully embodied the aspirations and the contradictions inherent the process of planned decolonization. Schools were built in most cases for religious institutions, engaged for centuries in evangelization and education of the natives. They presented a distinctly modernist architectural language of sun breakers and breathing walls but did not differ planimetrically and functionally from colonial buildings. The buildings proposed accurately sized spaces with respect

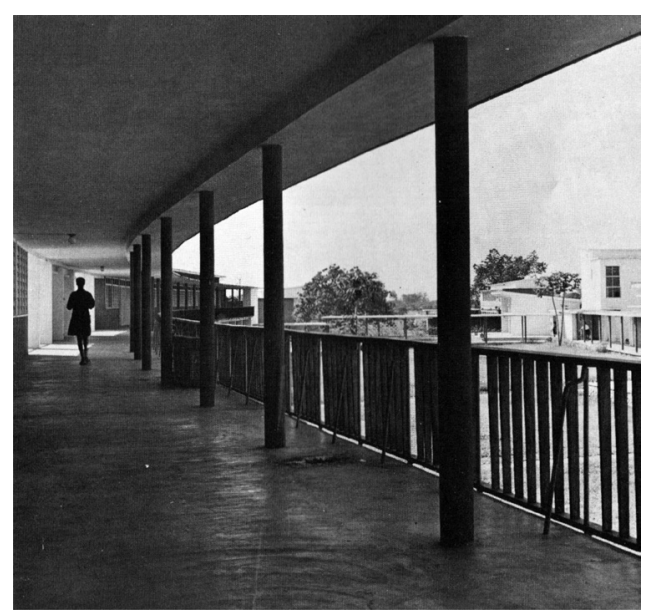

Figure 12. Fry\&Drew, Prempeh College, Kumasi, Ghana, 1952 from Fry, Drew, Knight, Creamer, Booklet, 1977. 
to climatic demands but were able to accommodate only Western educational methods, without any reflections on traditional teaching methods. The schools, far from becoming space of encounter, exchange and cultural mediation were above all a symbol of authority. The choice of building sites and urban systems of the Ghanaian schools resemble model villages illustrated in the small manual Village Housing in the Tropics ${ }^{63}$ published in 1947 as a pocket-book for English soldiers in West Africa. The schools as villages of knowledge, introverted spaces that housed a community no longer linked by centuries of tradition but by sharing modern rules and behaviors. An ideal community able to be the foundation for the development of a continent that lived in fully modernlooking spaces.

Schools seek to establish a dialogue with the surrounding landscape, denying any rigid symmetrical mesh and creating a subtle affair of counterpoise and space $e^{64}$. In many schools a central space with classrooms build a scenic backdrop for the meeting hall or the church, sometimes completed with a tower, the classic symbol of authority. Schools, re-proposing rather superficially traditional villages, were to present the image of a set of elements carefully related in an informal manner ${ }^{65}$. Drew will say of the schools, without in any sense copying African detail we wanted to give a response which is African (...), moulded forms which are rythmical and strong, not spiky and elegant, but bold and sculptural ${ }^{66}$. Drew's ideas will be defined by Fry as instinctive architecture $^{67}$, an idea borrowed from Le Corbusier of a modern revival of the deep spirit of vernacular architecture understood as the result of an almost subconscious process of assimilation. Similarly Otto Königsberger identifies vernacular elements as an embryonic stage in the search for climate devices ${ }^{68}$.

The Ghanaian schools by Fry\&Drew are the most brilliant applications of design tools presented in the manual and Prempeh College ${ }^{69}$ in Kumasi is the example of the maximum variability of solutions. It is a school that stands on a small hill just outside the city center and follows the principles of orographic adaptation set forth in Village Housing in the Tropics. The school campus becomes a micro-village where the circulation system is provided by the extensive use of covered walkways, allowing transit to students in constantly shaded areas. The different functional elements such as classrooms, dormitories, auditoriums and laboratories are attached to this pedestrian infrastructure. The slight curvature of the buildings allows a clearer delimitation of the interior space that ends with two elements of a larger scale: the assembly hall and the canteen. The overall system is a compromise between the guidance rules set out in the manual and the site's specific needs: the classrooms blocks are oriented south and not north in order not to interrupt the long connective walkway. 
The use of a common structural pattern determines a single depth for all the buildings that are then characterized by different choices in section and facade. The classrooms are oriented east-west and have a large veranda in the northern facade and a monumental solar shading system of box elements in enameled wood in the southern one. The sizing of the device is particularly interesting as the need to prevent direct solar radiation collides with that of ensuring lighting and views to the outside because the most concentrated and sustained work of a school takes place in classrooms and the architect's job is to make such work not only possible, but enjoyable ${ }^{70}$. The verification through the shadow angle protractor shows how the slight tilt of the horizontal sides of the box and its depth, allows to avoid direct radiation while maintaining a 50x50 pattern that ensures the possibility to look outside. In the dormitory blocks the northsouth orientation leads to radically different solutions: a breathing wall with rectangular openings on the west side closes the veranda with louvre windows which is used as a separate distribution space. The east facade, described in the manual as particularly critical, is resolved with lugs to avoid direct radiation, while the ventilation is forced by positioning offset openings in the two opposite walls, to create an internal air turbulence. The different coverage and ventilation systems, facade solutions in addition to the choice of materials, make Prempeh College a splendid example of how the issues outlined in the manual can be declined in different ways within the same building.

The Ghanaian schools as a whole return the physical image of Africa envisioned by Fry\&Drew: a continent, where modern rationality acts with respect to local traditions and in which the analysis of climatic factors becomes a guidance for the development of an architecture deeply rooted in the context yet cosmopolitan. Architecture in the humid tropics is a collaboration with nature to establish a new order in which human beings may live in harmony with their surroundings ${ }^{71}$. The design system of Tropical Architecture mediates local

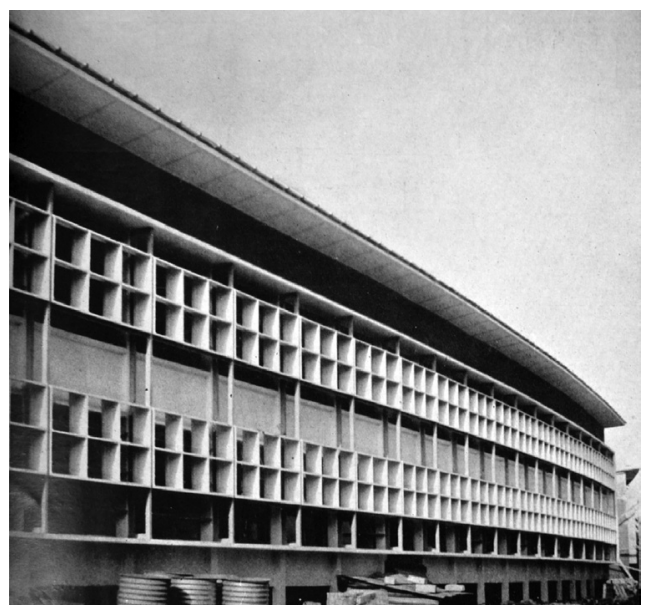


conditions and climate with imported construction techniques and materials on a path towards the achievement of a truly African architectural language ${ }^{72}$, variable and constantly modernized. The design system produces functional spaces with a hybrid aesthetic: the symbol of the idealistic aims of progressive colonialism. The educational programs are comparable, in terms of design innovations, with school programs of postwar Europe. Tropical Architecture transcends European and global modernism to become a distinct architectural language: technocratic and regional.

\section{APPENDIXES, THE OPERATIVE TOOLS}

The manual is concluded with a substantial number of appendixes that are to be considered the true operating tools at the end of a text that, given the functional distinction of the chapters, tends to repeat itself. The two parts of the manual should be read in a continuous comparison: the text introduces themes and sets guidelines, appendixes identify computing systems and propose solutions. On the one hand a theoretical apparatus, on the other complementary technical solutions both indispensable for the design approach. The appendixes are seventeen in total and touch different issues: planting in tropical areas, protection of buildings from termites, costs of construction, air conditioning systems, etc.

The list is an update of what Daniel Heandrick called Tools of Empire ${ }^{73}$; specific objects conformed by experimental processes such as bungalows and solar topees are replaced by open systems for calculation and design. New tools of modernity are, for example, systems for calculation and management of solar radiation. The systems, which by their nature can be difficult to understand for designers with no specific background in complex geometry, are always shown through concrete examples, in this case the use of solar paths to model plans and the facades. Instruments such as the Heliodon and the Pleijel Sundial ${ }^{74}$, used to

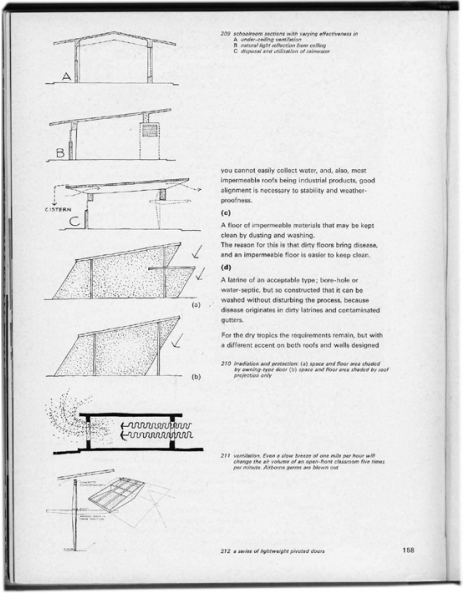

Figure 14. Edwin Maxwell Fry and Jane Drew, Tropical Architecture in the humid zones (London: Batsford, 1956), 159.

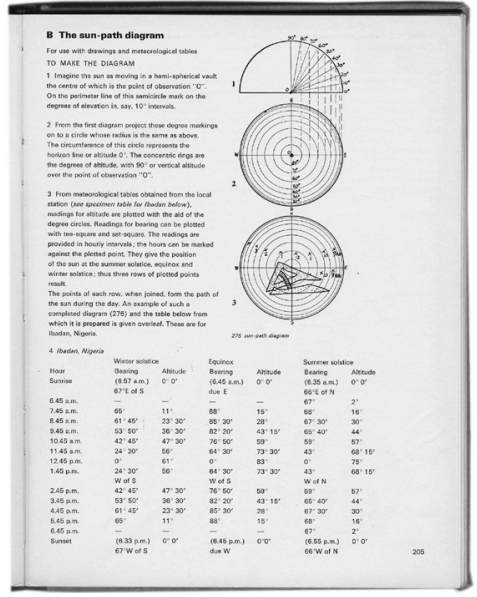

Figure 15. Edwin Maxwell Fry and Jane Drew, Tropical Architecture in the humid zones (London: Batsford, 1956), 205. 
verify the correct application of computing systems, are also presented in the appendixes. Most of the appendixes face specific problems for certain areas within the tropical belt or propose solutions for specific parts of the building. The protection from termites leads to reflections on the shaping of the building base, the defense from lightning is an additional factor to consider in sizing overhangs for sun protection, the need to identify storage areas and stormwater conservation tanks brings planimetric changes. An appendix is dedicated to the performances of various materials in the tropics and lists in a table the virtues and defects of each material by providing specific references to scientific studies.

The manual concludes with a long discussion on purely technical matters but overall the work can not be considered as a simple attempt to technological advancement of the underdeveloped tropical areas. Rather than a technological manual Tropical Architecture is a handbook of ideas and attitudes: the optimism in science as a mean of improving living conditions at a global scale, the confidence in the partnership and encounter between different cultures, the inevitability of progress, seen not as a unifying factor but as occasion of specificity, the consideration of climate as a difficult starting point of the project and at the same time as an engine for a new architectural rootedness. An architecture shaped by environmental conditions in a ant-rhetorical and antilocalist way, an innovative interpretation of European modernism in which the climate, the topography and the encounter with local cultures invigorate and fortify the design. Fry in a speech at the RIBA in 1979 will say: we were fated to make a new architecture out of love of place ${ }^{75}$.

In the epilogue of the first version of the manual in 1956, strangely disappeared in the final version of 1964, Fry\&Drew presented a general valedictory note on aesthetics in the humid tropics ${ }^{76}$. Aesthetic considerations, carefully avoided throughout the book, are clearly stated here constituting the personal interpretation of the presented attitude, It is our conclusion that where nature is most rampant and wild, geometrically cut sculptural forms containing strong rhythmical patterns are satisfactory ${ }^{77}$. The aesthetic character of tropical architectural is given by the use and control of shading and ventilation, aesthetics can only confirm what the weather dictates. Tradition can be absorbed in contemporary architecture, as long as it remains an influence and not a model to be copied. It is the spiritual quality of an architect's work that matters, which to achieve, mastering the technical facts with human needs and aspirations, calls for deep and sustained feelings, and the capacity to live life fully. With these attributes he can create civilization ${ }^{78}$. 
NOTES

The first version of the book was published in 1956 and only differs for a few details from the final version, Edwin Maxwell Fry and Jane Drew, Tropical Architecture in the humid areas (London: Batsford, 1956). The initial idea of the authors was to create two separate volumes dedicated to the humid and dry tropics but the little success of the first manual pushed the implementation of a new book including both areas.

Mark Crinson, Modern Architecture and the End of Empire (Farnham: Ashgate, 2003), 132-137. The book was published by Fry\&Drew at the end of their long Indian experience and provides examples of architecture built in Chandigarh by the authors and by their colleagues such as Le Corbusier, Pierre Jeanneret and Balkrishna Doshi.

Edwin Maxwell Fry, Maxwell Fry Full Autobiography, 1985, F\&D Archive Box 14, RIBA Archive, London, UK.

The book is actually dedicated to Otto Königsberger, one of the key figures in the development of the Department of Tropical Architecture at the Architectural Association in London.

Edwin Maxwell Fry, Jane Drew, Tropical Architecture in the dry and humid zones (London: Batsford, 1964), 17-18.

Ibid.

Edwin Maxwell Fry, Fine Buildings (London: Faber\&Faber, 1944), 4.

Ibid. 2.

Walter Gropius, Scope of Total Architecture (New York: F. W. Dodge Corporation, 1943), 20.

Edwin Maxwell Fry, Fine Buildings (London: Faber\&Faber, 1944), 115.

Ibid. 124.

Ove Arup, was Fry's personal friend as evidenced by numerous letters in the RIBA Archive and was the engineer of all the African works. Jane Drew, "Recent Work by Fry \& Drew \& Partners in West Africa" in Architectural Design, May (1955).

Edwin Maxwell Fry, Jane Drew, Tropical Architecture in the dry and humid zones (London: Batsford, 1964), 25.

The School in Amedzofe, a small town in the Volta Region in Ghana, was the first constructed by Fry \& Drew in Africa and also one of the simplest in terms of layout and climatic devices. Edwin Maxwell Fry, “African Experiment” in Architectural Review, May (1953).

The images were published in Ove Arup, "New Building Techniques in the Tropics" in Conference on Tropical Architecture, 95-101, (London: University College, 1954).

Many construction companies operating in Africa in the 50's and 60's were established by Italian immigrants, among many it is worth mentioning the Micheletti Constructions operating in Ghana since 1955 and Cappa and D'Alberto opened in Nigeria in 1932 and main contractor of Ibadan University.

The breathing walls with African motifs have become the trademark of Tropical Architecture, the most iconic are undoubtedly those of the Kenneth Dike Library in Ibadan, the first example is the balcony of Adisadel College residences in Cape Coast.

Alfred Alcock, was Town Engineer of Kumasi, from 1936 to 1945, and then became Gold Coast Town Planning Advisor from 1945 until 1956. Working in Kumasi, Alcock became a pioneer in the creation of villages through self-construction. Iain Jackson, Jessica Holland, The Architecture of Edwin Maxwell Fry and Jane Drew (Farnham: Studies in Architecture Ashgate, 2014).

Walter Gropius, Scope of Total Architecture (New York: F. W. Dodge Corporation, 1943), 88.

Edwin Maxwell Fry, Jane Drew, Tropical Architecture in the dry and humid zones (London: Batsford, 1964), 22.

Tema Manhean was a project constructed by Fry\&Drew in order to move a small fishing village following the first steps of the Volta River project see Iain Jackson, Rexford Assasie Oppong, "The planning of late colonial village housing in the tropics: Manhean Tema, Ghana," Planning Perspectives, Volume 29, Issue 4 (2014) 475-499. 
Edwin Maxwell Fry, Jane Drew, Tropical Architecture in the dry and humid zones (London: Batsford, 1964), 22.

Ibid.

Ibid. 24

The shadow angle protractor is a simplified tool for the calculation of the sun paths regarding latitude and longitude. The instrument was considered particularly useful to calculate the shading of surfaces, since its use is quite easy for those who have no specific knowledge of trigonometry. Edwin Maxwell Fry, Jane Drew, Tropical Architecture in the dry and humid zones (London: Batsford, 1964), 29.

Mark Crinson, Modern Architecture and the End of Empire, (Farnham: Ashgate 2003) 132-137.

Building Types were standard projects designed mainly by military engineers for British colonies see Anthony King, The Bungalow 1600-1980 A study of the cultural, social, political and economic factors in the production of a global house-type, (Brunel University PhD Thesis 1982). John Michael Weiler, Army Architects, The Royal Engineers and the Development of Building Technology in the Nineteenth Century (University of York PhD thesis 1987).

Edwin Maxwell Fry, Jane Drew, Tropical Architecture in the dry and humid zones (London: Batsford, 1964), 42.

The Architects'Co-Operative Partnership (ACP) was founded in London in 1939. The study comprised 11 members, all recently graduated from the Architectural Association who wanted to work in an environment without hierarchies and in projects with a strong social value. Their method was strongly influenced by Berthold Lubetkin's Tecton. The African projects of the group, who opened a studio in Lagos in the 50's, were followed by Leo De Syllas. The other founders were: Kenneth Capon, Peter Cocke, Michael Cooke-Yarborough, Anthony Cox, Michael Grice, AW Nicol, Anthony Pott, Michael Powers, Greville Rhodes and John Wheeler

Edwin Maxwell Fry, "West Africa" in Architectural Review, July (1960).

"Overseas Review" in Architects Building News, May, (1959).

Edwin Maxwell Fry, Jane Drew, Tropical Architecture in the dry and humid zones (London: Batsford, 1964), 64.

Ibid. 74.

Ibid. 54 .

The house at Ahmedabad by Balikrishna Doshi, is clearly inspired by Le Corbusier exploring the potentials of concrete buildings in tropical areas see William Curtis, Balikrishna Doshi: An Architecture for India (New York: Rizzoli, 1988).

The W. R. Healy House nicknamed Cocoon House is a small guest-house built in 1950 in Sarasota, Florida, the house allowed Paul Rudolph to achieve world fame thanks to the publication in John Peter, Masters of modern architecture (New York: G . Braziller, 1958).

In the manual there are shown different works by Amancio "Pancho" Guedes including the Twin Houses and Leite House in Lourenco Marques (now Maputo) in Mozambique see Pancho Guedes. Vitruvius Mozambicanus (Lisbon: Colecção Museu Berardo, 2009).

James Cubbitt \& Partners was founded in 1947 in London by Cubbitt with three partners: Fello Atkinson, Stefan Buzas and Dick Maitland, all from the Architectural Association. In 1950, the study opened an office in Lagos and constructed numerous buildings both in Nigeria and in Ghana. Otto Königsberger, "Tropical Architecture” in Architectural Design, January, (1954).

Ministry of Education, Community Centres (London: Ministry of Education, 1954), 3.

Kofi Antobam was the pioneer of visual art in Ghana between the 50's and 60's. Antobam's work presents natural proportions of humans in complex compositions, realistic content and scenes of everyday life in Ghana see Atta Kwami, Kofi Antubam, 1922-1964: A Modern Ghanaian Artist, Educator, and Writer in A Companion to Modern African Art edited by Gitti Salami and Monica Blackmun Visonà (Hoboken: Wiley-Blackwell, 2013).

The Ga people live in southeastern Ghana, in the area of the capital Accra, and in neighboring Togo. The Ga people founded the city of Accra in the sixteenth century as a trading port and took the name from the ancient kingdom of Ga Nkran, founded in 1510 and ruled by the sovereigns Ga Mantse. 
Iain Jackson and Jessica Holland, The Architecture of Edwin Maxwell Fry and Jane Drew (Farnham: Studies in Architecture Ashgate, 2014), 194.

Walter Gropius, Scope of Total Architecture (New York: F. W. Dodge Corporation, 1943), 188. Edwin Maxwell Fry, Jane Drew, Tropical Architecture in the dry and humid zones (London: Batsford, 1964), 143.

H.M.S.O., Report on the commision on higher education in the colonies (London: Colonial Office 1945), 128.

Edwin Maxwell Fry, Fry Letter to the Inter University Council, 1947, F\&D Archive, RIBA Archive, London, UK.

The extraordinary story of the establishment of the Ghana librarian system is narrated in first person by Evelyn Evans, A Tropical Library Service, the story of Ghana's Library (London: André Deutsch 1964).

"Commonwealth architecture" in Architects and Building News, May (1957). Edwin Maxwell Fry, "West Africa" in Architectural Review, July (1960).

Edwin Maxwell Fry, Fry Letter from Maxwell Fry in Ibadan to Jane Drew in Chandigarh, 1953, F\&D Archive, RIBA Archive, London, UK.

"Work in the Tropics by Drake \& Lasdun" in Architectural Design, February, (1958), 78-79. "Museum at Accra” Architectural Review, June (1957), 440-444.

Lindsay Drake joined the studio of Fry\&Drew as a partner in 1949 alongside Denys Lasdun and will remain in the studio until he retired in 1959. Drake came from the experience of Tecton with Berthold Lubetkin. The role of Denys Lasdun inside the studio was minimal so rather than collaboration it is possible to talk about cohabitation. The last African projects of Fry\&Drew study were followed by Drake: Mfantsipim School, Ghana Commercial Bank and the National Museum. I draw these considerations from Barnabas Calder, "Cohabitation or collaboration? Drake Lasdun of Fry and Drew Drake \& Lasdun" (paper presented at Liverpool School of Architecture, The Influence of Fry \& Drew Conference, 10 October 2013).

W. Lawrence, R. Merrifield, "The National Museum of Ghana” in Museums Journal July (1957) 88. KwameNkrumah was the firstpresident of Ghanain 1957 and the firstpresident ofanAfrican state in the process of decolonization see Kwame Nkrumah, Africa Must Unite (Londn: Heinemann 1962). Ama Biney, The Political and Social Thought of Kwame Nkrumah (New York: Palgrave McMillan 2011). F.M. Bourret, Ghana: The Road to Independence, 1951-1957, (Stanford: Stanford University Press 1960).

Ernest Renan, What is a Nation? in Homi Bhabha, Nation and Narration (New York: Routledge 1990), 19.

Mark Crinson, Modern Architecture and the End of Empire, (Farnham: Ashgate 2003) 153.

Edwin Maxwell Fry, Jane Drew, Tropical Architecture in the dry and humid zones (London: Batsford, 1964), 155

Ola Uduku, The Colonial Face of Educational Space in Lesley Naa Norle Lokko, White Papers, Black Marks: Architecture, Race, Culture (Minneapolis: University of Minnesota Press 2000) 45-65. Jane Drew, Edwin Maxwell Fry, Harry 1. Ford, Village Housing in the Tropics, With Special Reference to West Africa, (London: Humphries, 1947).

Edwin Maxwell Fry, Jane Drew, Tropical Architecture in the humid zones (London: Batsford, 1956), 73.

Mark Crinson, Modern Architecture and the End of Empire, (Farnham: Ashgate 2003) 139.

Jane Drew, "Recent work by Fry, Drew, Drake \& Partners in West Africa" in Architectural Design, May (1955), 299-300.

Edwin Maxwell Fry, Art in a Machine Age (London: Methuen 1969), 8.

Vandana Baweja, A Pre-history of Green Architecture: Otto Königsberger and Tropical Architecture, from Princely Mysore to Post-colonial London (Ann Harbour: University of Michigan 2008).

Jane Drew, "Recent Work by Fry\&Drew\&Partners in West Africa" in Architectural Design, May (1955). Otto Koenisberger, "Tropical Architecture" in Architectural Design, January (1954). Edwin Maxwell Fry, “African Experiment” in Architectural Review, May (1953). 
Edwin Maxwell Fry, Jane Drew, Tropical Architecture in the dry and humid zones (London: Batsford, 1964), 161.

Edwin Maxwell Fry, Jane Drew, Tropical Architecture in the humid zones (London: Batsford, 1956), 86.

Rhodri Windsor Liscombe, "Modernism in Late Imperial British West Africa: The Work of Maxwell Fry and Jane Drew, 1946-56" in Journal of the Society of Architectural Historians, Vol.65, No.2 (2006),188-215.

Daniel Headrick, The Tools of Empire: Technology and European Imperialism in the Nineteenth Century, Oxford: (Oxford University Press 1981).

The instrument was invented by Swedish architect Gunnar Pleijele and is a simplification of the Heliodon allowing with fewer tools to control solar radiation on scale models. Iain Jackson, Jessica Holland, The Architecture of Edwin Maxwell Fry and Jane Drew (Farnham: Studies in Architecture Ashgate, 2014), 156. 1956), 252. 
Crinson, Mark. Modern Architecture and the End of Empire. Farnham: Ashgate, 2003.

Drew, Jane, Edwin Maxwell Fry, Harry 1. Ford. Village Housing in the Tropics, With Special Reference to West Africa. London: Humphries, 1947.

Evans, Evelyn. A Tropical Library Service, the story of Ghana’s Library. London: André Deutsch 1964.

Folkers, Antoni. Modern Architecture in Africa. Amsterdam: SUN 2010.

Fry, Edwin Maxwell and Jane Drew. Tropical Architecture in the humid areas. London: Batsford, 1956.

Fry, Edwin Maxwell. Art in a Machine Age. London: Methuen 1969.

Gropius, Walter. Scope of Total Architecture. New York: F. W. Dodge Corporation, 1943.

Headrick, Daniel. The Tools of Empire: Technology and European Imperialism in the Nineteenth Century. Oxford: Oxford University Press 1981.

Jackson, Iain and Jessica Holland. The Architecture of Edwin Maxwell Fry and Jane Drew. Farnham: Studies in Architecture Ashgate, 2014.

Lokko, Lesley Naa Norle. White Papers, Black Marks: Architecture, Race, Culture. Minneapolis: University of Minnesota Press, 2000.

Mercer, Kobena. Cosmopolitan Modernisms. Cambridge: MIT Press 2005.

Muthesius, Stefan. The postwar university: utopianist campus and college. Cambridge: MIT Press 2000 .

Njoh, Ambe. Planning power: town planning and social control in Colonial Africa. London: University College 2007.

Thompson, A.R. Education and Development in Africa. New York: St. Martin's Press, 1981.

Uduku, Ola. Africa beyond the post-colonial: political and socio-cultural identities. London: Aldershot, 2004.

Uduku, Ola. Architecture and Building Forms: A review of architecture and building form in West Africa. Accra: EPP Book Services, 2012. 


\section{ATMOSFERSKE DIMENZIJE ARHITEKTURE}

\section{Anđela Karabašević}

U ovom radu predlažem četiri metodološka alata za naučno istraživanje arhitektonske atmosfere: objektivno iskustvo, holistička mera, kompjuterska simulacija i atmosferska vizualizacija. Ovi alati su proistekli iz šireg istraživačkog opsega zasnovanog na hipotezi da efemerni efekti - svetlosti, toplote, zvuka, mirisa - koji se manifestuju u vazduhu ili kroz vazduh, predstavljaju naučnu osnovu za precizno konstruisanje atmosfere u arhitekturi. Opisivanjem sopstvene istraživačke metodologije na primerima individualnih studija slučaja, braniću stav da se arhitektonska atmosfera može naučno istražiti i tačno konstruisati, i da atmosferski pristup arhitektonskom istraživanju i projektovanju nudi novo neprocenjivo saznanje o nevidljivim vazdušnim procesima koji određuju čovekov osnovni doživljaj prostora.

KLJUČNE REČI: ARHITEKTONSKA ATMOSFERA, ATMOSFERSKA METODOLOGIJA, OBJEKTIVNO ISKUSTVO,

HOLISTIČKA MERA, KOMPJUTERSKA SIMULACIJA, ATMOSFERSKA VIZUALIZACIJA

\section{KOSMOPOLITSKI PRIRUČNIK ZA DEKOLONIJALIZOVANU AFRIKU - TROPSKA ARHITEKTURA U SUVIM I VLAŽNIM ZONAMA PREMA FRIJU I DRUOVOJ \\ Jacopo Galli}

Edvin Maksvel Fri (Edwin Maxwell Fry) i Džejn Dru (Jane Drew), iako su poznati po svojoj ulozi u izgradnji Čandigara zajedno sa Le Korbizjeom, njihovom indijanskom iskustvu prethodila je duga karijera u Zapadnoj Africi koja je započeta tokom Drugog svetskog rata i trajala je do kraja 50-ih godina. Fri i Druova bili su aktivni u Gani i Nigeriji u izgradnji velikog broja objekata: škola, univerziteta, kuća, sela, poslovnih zgrada i muzeja. Njihovo iskustvo na terenu pretočeno je u knjigu Tropska arhitektura u suvim i vlažnim zonama (Tropical Architecture in the Dry and Humid Zones) konačno objavljenu 1964. godine. Ovaj rad ima za cilj da analizira njihovo uputstvo kao pokušaj da se uspostavi kosmopolitski i savremeni sistem za projektovanje specifičan za tropske predele. Eksperimentalni i naučni pristup koji je klimatskim podacima pronašao alat za stvaranje nove zasnovanosti moderne arhitekture ne oslanja se na analizu kulture ili reinterpretaciju vernakularnog, već na složenu analizu lokalnih uslova kako bi se došlo do odgovarajužih projektantskih rešenja. Tropska arhitektura u suvim $i$ vlažnim zonama predstavlja manifest regionalnog modernizma, dva naizgled suprotna koncepta koja su pomirena u projektantskom pristupu kojim se pokušava izgraditi nova kosmopolitska modernost.

KLJUČNE REČI: FRI\&DRU, TROPSKA ARHITEKTURA, GANA, NIGERIJA, AFRIKA, KLIMATSKI ZASNOVANO

PROJEKTOVANJE, KOSMOPOLITIZAM

\section{OD KINETIZMA DO KINETIČKE ARHISKULPTURE Nikola Marković}

Ovaj tekst predstavlja kratak esej o razvoju i nastanku kinetičkih arhiskulptura uz osvrt na istorijat refleksija umetničke prakse i razvoja kinetizma kroz umetnost i arhitekturu (u periodu od XVIII veka do danas). Poseban akcenat dat je sagledavanju kinetičkih pojavnosti arhiskulptoralnih objekata kao sve prisutnijih pojava inovativnog jezika savremene arhitekture sa kraja prošlog i početka ovog veka. Rad takođe ukazuje i na dug istorijski put od najranijih iskustava pokreta u umetnosti do sadašnjeg proučavanja vrednosti kinetizma i arhiskulptoralnosti na polju razvoja savremene interaktivne kinetičke arhitekture. 